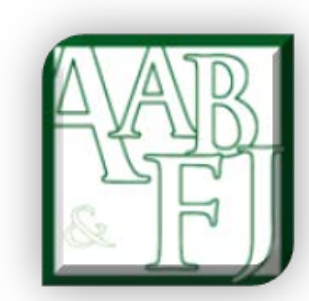

\title{
Interlocking Directorship in New Zealand
}

\author{
Jamal Roudaki ${ }^{1}$ and Md. Borhan Uddin Bhuiyan²
}

\begin{abstract}
The aim of this research is to identify the determinants and consequences of interlocking board membership in New Zealand and whether this interlocking affects the firm performance. This research used a sample of 276 firm years and 1,783 directors from New Zealand listed companies. A two-fold approach analysing the overlap of directors' names, boards, and company levels was used.

This research finds that New Zealand firms are highly interlocked. While concentrated ownership firms react negatively to interlocking, this research finds that interlocking is negatively impacting firm performance in New Zealand. This research also finds that New Zealand firms were significantly interlocked under both approaches, which resulted in negative firm performance.

This study has wide application to the New Zealand Financial Market Authority and Institute of Directors New Zealand to evidence the possible effects of directors of being involved ("busy") in more than one company at the same time.

This is the first paper on firm and board interlocking based on New Zealand stock exchange data following the corporate governance best practice code 2004 regime which identified both the determinants and consequences of interlocking.
\end{abstract}

\section{JEL Classification: M40}

Keywords: board independence, CEO interlock, interlocking director, interlocked company, firm performance, New Zealand

\footnotetext{
${ }^{1}$ Lincoln University, New Zealand. jamal.roudaki@lincoln.ac.nz corresponding author.

${ }^{2}$ Massey University, m.b.u.bhuiyan@massey.ac.nz
} 


\section{Introduction}

The aim of this research is to identify the determinants of firms having interlocking directors in their boards. We also examine the consequences of interlocking board relationships in whether interlocking affects firm performance. Interlocking occurs when a director sits on his or her own company board but also on at least one other board. Empirical research suggests that firms with a higher level of interlocked board members can gather diversified expertise and experience which helps firms to improve the managerial decision making process and causes higher firm performance. Alternatively, interlocks have become the primary indicator of inter-firm network ties which helps to identify them in publicly available information from highly reliable sources (Devos, Prevost \& Puthenpurackal, 2009). Presence of interlocking board members and connected boards may compromise the effectiveness of board monitoring with respect to the setting of directorial and CEO compensation. Therefore, interlocking board members may create an alternative "power house" within the network to deprive shareholders of some influence. However, the behaviour of interlocking directorship is unknown when the firm is strictly in an ownership controlled environment. Any impact of interlock on the information asymmetry environment is yet to be investigated.

The corporate centrality in New Zealand is relatively new following the economic shift towards capitalism in late 1980. A lower level of corporate centrality extant in the early 1970's became more interlocked to capture business and political power following the economic shift (Murray, 2006). A recent survey by Parker (2012) indicates that 15 percent of directors serve more than one board and out of the interlocking directors, 25 percent of female directors' served on more than one board. Recently, the Financial Market Authority New Zealand (2013) issued a best practice guide for directors and emphasized the importance of 'dedicated time' from directors to the directorial role. The report argues that directors can only add value if they spend the time which the company requires in order to professionally carry out their duties.

Extant literature on the effect of interlocking directorship is not conclusive. Following the 'reputation' hypothesis, directors holding multiple board appointments have the advantage of allowing them to learn about different management styles and to enhance their skills. Alternatively, the 'busyness' hypothesis predicts that interlocking board member will devote less attention to each of the boards and/or to prefer one board to another in terms of time use and, ultimately, cause lower performance in the second company. In a recent stream of interlocking literature Bowen, Rajgopal and Venkatachalam (2008) find that firms with more interlocked directors on the board exercise greater accounting discretion, potentially contributing to excess CEO compensation. Contradictory findings in different countries enhance further research on board interlocking and performance.

The managerial labour market in New Zealand, while different from other countries, is criticised due to the lack of qualified independent directors (Goldfinch, 2004). Relaxed monitoring and less pressure on independent directors (Farrar, 2005) along with the shortage of company directors (Bhuiyan \& Habib, 2011) creates a unique environment in New Zealand for corporate governance research and directors' 'busyness' related to interlocking board members.

Using a sample of New Zealand listed companies from 1999 - 2011, this research aims to examine the determinants of board interlocking in New Zealand. This research will also extend the work of Bhuiyan and Habib (2011) to see the effect of interlocking directorship on firm performance in New Zealand. A significant contribution of this research is related to higher 
ownership concentration in New Zealand, relative to most developed capital markets (United States, UK and Australia). The New Zealand business environment is comparatively close enough for familiarity to arise between people in the same (or similar) professions and therefore the possibility of professional networking is higher than in the USA and UK. Moreover, high ownership concentration created information asymmetry and agency problems (Hossain et al., 2001) in the New Zealand context. This research also aims to split ownership between managerial ownership, institutional ownership, government ownership and individual ownership and to examine how different ownership interacts with multiple directorships.

The paper proceeds as follows. Section two provides relevant literature and the conceptual arguments of board interlocking. Section three explains research methods and data research design. Section four presents the result discussion while section five concludes the paper with remarks and comments on future research.

\section{Literature Review}

Outside directorship serves as an important incentive for directors to enhance their reputation as monitoring specialists (Fama and Jensen, 1983). Following this, Mace (1986) argues that outside directorships are perceived to be valuable because they provide executives with prestige, visibility and commercial contacts. Early research indicates that busy directors are beneficial for the business as they have more diversified expertise and experience. Biggins (1999) posits that diverse boards help to better represent all shareholders, nurture better appreciation of 'intangibles' such as work/life balance issues and can help recruit and retain top executive women and minorities”. Singh, Vinnicombe, and Johnson, (2000) argue that lack of diversity in boards can be associated with negative performance, especially where boards are highly interconnected (e.g. through interlocking directorships), while Mattis (2000) contends that lack of diversity on a board can contribute to a dearth of critical thinking and innovation.

Fama and Jensen's (1983) interlocking directorship research follows two different hypotheses. Firstly, the interlock may indicate the director's quality. Directors having multiple seats on different organisations' boards' signals wider acceptance of his/her expertise and sincerity in their profession. If this is true, then multiple directorships will enhance active monitoring and reduce agency costs. Therefore it would result in enhancing shareholders' confidence and lead to higher stock price. Secondly, and in contrast, directors with too many outside board seats may be so busy that they do not function as effective monitors. The diminishing oversight may cause more severe agency costs as managers serve to further their private benefits at the expense of shareholders and may cause an inverse relation between higher outside directorships and market return. Existing research has been scant in examining the effect of concentrated ownership, managerial discretion and market price. This research aims to enhance the knowledge about multiple directorships within the New Zealand context of ownership structure.

New Zealand has a unique business environment with concentrated ownership which may cause mechanisms of corporate governance to be ineffective. The concentrated ownership also creates a possible environment of interlocking relationship among the firms. Silva, Majluf and Paredes (2006) suggest that firms' performance may be affected by their ownership - control structure and the "social ties" of the firm. They categorised a social tie as family ties and interlocking directorship. Mizruchi (1996) reports that the interlocking of directors facilitates the transfer of information, brings high cohesion and diminishes the probability of opportunistic 
behaviour. In contrast, the effect of social ties is negative if family relationship and the interlocking of directors are used to extract value from the firm at the expense of minority shareholders.

Existing research evidence that interlocking is decreasing in different geographical location. Roy, Fox and Hamilton (1994) examined the changes in interlocking directorates for all listed companies on the New Zealand Stock Exchange in the year 1987, 1990 and 1993. Their results showed a decrease in the number of potential director interlocks from 5.6 in 1987 to 3.3 in 1993. Using a sample of 2001-2003; Devos et al. (2009) found that interlocks declined from 71 in 2001 to 29 in 2003 and evidence that interlock does not significantly reduce a firms' value.

Existing literature emphasizes that independent directors are good monitors but increasing independence may not result in improved monitoring in all circumstances. Interlocking directors reflect a subset of independent directors and they represent a large percentage of total independent directors (Keys \& Li, 2005). These directors served on multiple boards and are categorised as 'career oriented directors'. Interlocking board members are always open to the concern that they might "shrink" their duties in response to the time demands of their many directorships. Alternatively, the risk of shrinking behaviour may be overcome by the benefit of experience that such directors can bring to a board (Hunton \& Rose, 2008).

Extant research studies have evidenced that poorly performing firms are more likely to interlock directors on their board and that the market reacts negatively to the announcement of directors appointment that creates interlock boards (Devos et al., 2009). Fich and Shivdasani (2006) show that firms in which a majority of outside directors hold three or more board seats have significantly lower market-to-book ratios than firms in which a majority of outside directors hold fewer than three board seats; the magnitude of this effect is economically meaningful too.

Beasley (1996) reports that the probability of committing accounting fraud is positively related to the average number of directorships held by outside directors. Ahn, Jiraporn and Kim (2010) examine the impact of multiple directorships on stockholders' wealth around the announcement of merger and acquisitions and argue that multiple directorships affect the quality of managerial oversight and thus influence agency conflicts in an acquisition decision. They found that multiple outside board seats induce negative announcement returns only when the number of multiple directorships reaches a higher threshold. Core, Holthausen, and Larcker (1999) report that busy directors set excessively high levels of CEO compensation, which in turn leads to poor firm performance. In contrast, Ferris, Jagannathan, and Pritchard (2003) find no relationship between the average number of directorships held by outside directors and the firm's market-to-book ratio. This research will elaborate on the existing literature to evidence the effect of board interlocking on managerial discretion and how shareholders are responding to board interlocking firms.

\section{Research Method and Data}

This section presents the measurement of board interlocking and firms' performance approaches that are used in this research. The following explanation describes data collection and regression models which were administered to examine as determinants of interlocking and performance effects. 
a) Measurement of board interlocking

The primary variable of interest for measurement of board interlocking is considered as the interlocking directorship exists if:

- A board of director is involved in outside board as board interlocking; or

- Companies involving each other through the directors as company-to-company interlocking

Board interlocking indicates ' $\mathrm{X}$ ' numbers of directors are sitting in ' $\mathrm{Y}$ ' number of other firm boards. Therefore, ' $\mathrm{Y}$ ' number is considering the board interlocking. Company to company interlocking indicates 'company Z' has interlocking (through the board member) with 'Q' number of companies. The total number counts to measure the interlocking for both board and companies.

b) Measurement of firm performance

Firm performance is measured using three proxies. First, return on assets, ratio of net income before tax and total assets. Second, return on sales, a ratio of net sales and total assets. Third, loss dummy, a dichotomous variable valued 1 if the firm has a negative profit during the financial year and 0 otherwise.

c) Data

Data related to firms and directors obtained primarily from the NZX deep archive for 1999-2011 proxy sessions in every alternative year (such as, 1999, 2001, 2003, 2007 and 2011). This study considers every alternate year to identify the interlocking variance assuming that interlocking position does not fluctuated much every year. The sample covers 276 firm years and includes a total of 1,783 board of directors' information. Foreign and subsidiary firms are excluded from the sample to obtain consistency and to reflect the purely New Zealand business environment. Financial institutes such as bank and insurance companies are also excluded as corporate governance structure and compliance for these firms are comparatively different than manufacturing and non-finance industry. Financial data such as sales, net income, total assets are collected from DATASTREAM.

\section{d) Empirical research method}

In order to investigate determinates of interlocking and performance effects, two regression models are administered to explore the statistical relationship. Firstly, determinants of board interlocking in equations (1) and (2) are considered that are labelled as interlocking determinates equations. Secondly, firm performance relationship with board interlocking investigated in equations (3) to (8) that are called interlocking effect equations.

\section{Interlocking determinants equations}

The first two regression models examine the determinants of board interlocking in New Zealand. The study models are as follows:

$$
\begin{aligned}
& \text { Interlock }_{\text {board of director }}=\partial_{0}+\partial_{1} \log \left(B O D_{-} S I Z E\right)_{t}+\partial_{2} \% B O D_{I N D_{t}}+\partial_{3} C E O_{\text {interlock }_{t}}+ \\
& \partial_{4} \text { TOP20_SHROWN } N_{t}+\partial_{5} C O D E_{t}+\partial_{6} \log (S A L E S)_{t}+\partial_{7} \log (T A)_{t}+\varepsilon \ldots \ldots \ldots
\end{aligned}
$$


Interlock $_{\text {company to company }}=\beta_{0}+\beta_{1} \log \left(B O D \_S I Z E\right)_{t}+\beta_{2} \% B O D_{I N D_{t}}+\beta_{3} C E O_{\text {interlock }_{t}}+$ $\beta_{4}$ TOP20_SHROWN $N_{t}+\beta_{5} C O D E_{t}+\beta_{6} \log (S A L E S)_{t}+\beta_{7} \log (T A)_{t}+\varepsilon \ldots \ldots \ldots$

2. Interlocking effects equations

The remaining equations (3-8) indicate the regression models for effects of board interlocking on firm performance. In equations 3 to 8 , firms' performance consider as a proxy for return on assets, return on sales and loss dummy of financial performance.

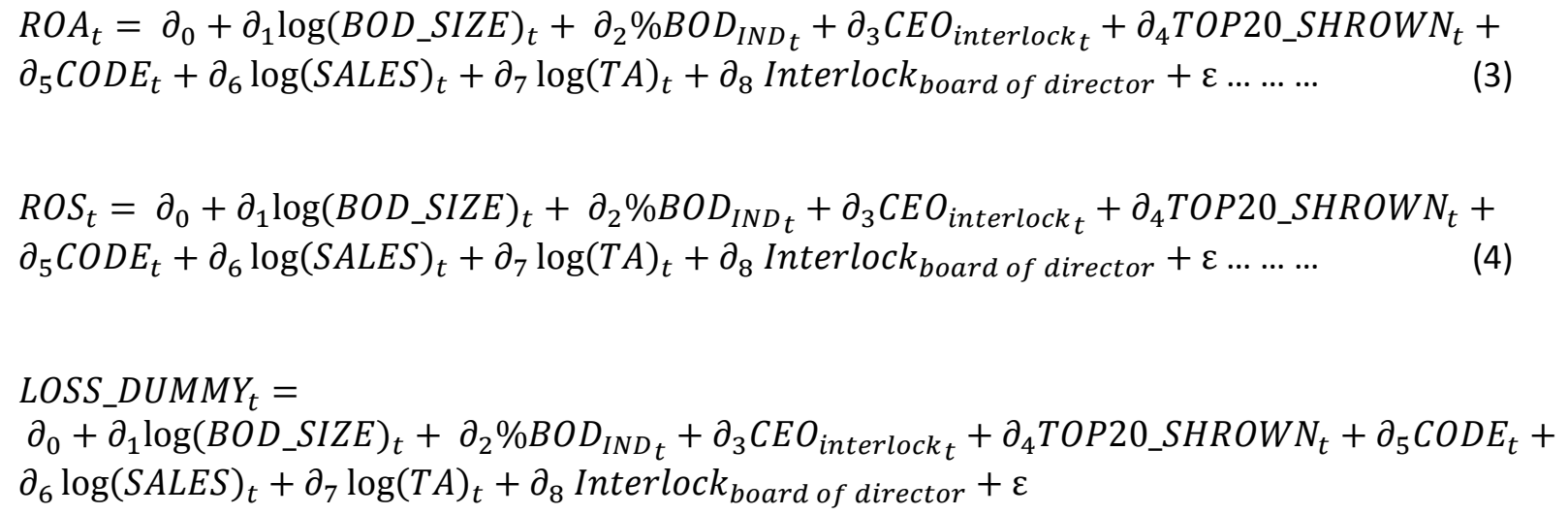

$R O A_{t}=\beta_{0}+\beta_{1} \log \left(B O D \_S I Z E\right)_{t}+\beta_{2} \% B O D_{I N D_{t}}+\beta_{3} C E O_{\text {interlock }_{t}}+\beta_{4}$ TOP20_SHROWN ${ }_{t}+$

$\beta_{5} C O D E_{t}+\beta_{6} \log (S A L E S)_{t}+\beta_{7} \log (T A)_{t}+\beta_{8}$ Interlock $_{\text {company to company }}+\varepsilon \ldots \ldots \ldots$

$R O S_{t}=\beta_{0}+\beta_{1} \log \left(B O D_{-} S I Z E\right)_{t}+\beta_{2} \% B O D_{I N D_{t}}+\beta_{3} C E O_{\text {interlock }_{t}}+\beta_{4}$ TOP20_SHROWN ${ }_{t}+$

$\beta_{5} C O D E_{t}+\beta_{6} \log (S A L E S)_{t}+\beta_{7} \log (T A)_{t}+\beta_{8}$ Interlock $_{\text {company to company }}+\varepsilon \ldots \ldots \ldots$

LOSS_DUMMY $=$

$\beta_{0}+\beta_{1} \log (\text { BOD_SIZE })_{t}+\beta_{2} \%$ BOD $_{\text {IND }}+\beta_{3}$ CEO interlock $_{t}+\beta_{4}$ TOP20_SHROWN S $_{t}+\beta_{5} C O D E_{t}+$

$\beta_{6} \log (S A L E S)_{t}+\beta_{7} \log (T A)_{t}+\beta_{8}$ Interlock $_{\text {company to company }}+\varepsilon \ldots \ldots \ldots$

Where;

Interlock board of director = total number of interlocking in the board with other firms board (board interlocking)

Interlock company to company = total number of interlocking in the board with other firms (company to company interlocking)

ROA = a proxy of firm performance, ratio of net income and total assets;

ROS = a proxy of firm performance, ratio of total sales and total assets;

LOSS_DUMMY = a proxy of firm performance, value of 1 if negative profit during the financial year, otherwise 0 . 
$\log \left(B O D_{\text {SIZE }}\right)$

$\% B O D_{I N D}$

CEO interlock

CODE

TOP20_SHROWN

Log (SALES)

$\log (T A)$
= natural log of total number of directors in the board;

= percentage of total number of independent board members;

= a dichotomous variable of CEO interlock measure. A value of ' 1 ' is assigned if CEO is an interlocking member and 'O' otherwise;

$=a$ dichotomous variable of 1 if observation is pre-corporate governance code, 0 otherwise;

= total percentage of share hold by the top twenty shareholder;

= log value of sales, a proxy of firm operating complexity;

= natural log of total assets as a proxy of firm size.

Table 1: Sample distribution

\begin{tabular}{|l|c|l|c|}
\hline \multicolumn{2}{|c|}{ Sample distribution } & \multicolumn{2}{c|}{ Yearly distribution } \\
\hline Details & Number & Industry & no. of sample \\
\hline Total listed companies in NZX till to date 2012 & 149 & Agriculture & 7 \\
\hline Companies doesn't cover full research period & 45 & Construction & 7 \\
\hline Companies listed in foreign stock exchange & 13 & Consumer & 28 \\
\hline Financial companies & 19 & Energy & 28 \\
\hline Interlocking director information is not available & 31 & Forestry & 7 \\
\hline & & Intermediate \& durables & 28 \\
\hline & & Leisure & 28 \\
\hline & & Media & 14 \\
\hline & & Mining & 21 \\
\hline & & Property & 14 \\
\hline & & Service & 42 \\
\hline & & Textile & 10 \\
\hline Total companies covered in the sample & & Transport & 42 \\
\hline
\end{tabular}

\section{Results}

Panel A of Table 2 contains the descriptive statistics of the variable used in the regression analyses. Average board interlocking in New Zealand is approximately 5 companies in number, while the board size median is 6 person (mean is 6.5 person). About 6 of the directors are independent on the board and CEO interlocks are detected in almost 33 percent of observations firm. About 14 percent companies are experiencing loss during the observation period. About 29 companies are interlocking each other with the interlocking directors in New Zealand. 43 percent of the companies are in pre-code period of observation with an average of 80.74 percent shareholding

concentration. 
Table 2 - Panel A: Descriptive Analysis

\begin{tabular}{|c|c|c|c|c|c|c|c|c|c|}
\hline \multirow{2}{*}{ Variables } & \multirow{2}{*}{ Mean } & \multirow{2}{*}{ Median } & \multirow{2}{*}{ Mode } & \multirow{2}{*}{ Std. Deviation } & \multirow{2}{*}{ Minimum } & \multirow{2}{*}{ Maximum } & \multicolumn{3}{|c|}{ Percentiles } \\
\hline & & & & & & & 25 & 50 & 75 \\
\hline BODINTERLOCK NO. BOD. BUS & 5.255 & 5.000 & 6.000 & 2.115 & 0 & 13.000 & 4.000 & 5.000 & 6.000 \\
\hline BODINTERLOCKNO. COM.BUS & 28.873 & 23.000 & 22.000 & 22.811 & 0 & 110.000 & 13.000 & 23.000 & 39.000 \\
\hline$C O D E$ & 0.433 & 0 & 0.000 & 0.496 & 0 & 1.000 & 0.000 & 0 & 1.000 \\
\hline BODSIZE & 6.484 & 6.000 & $\underline{6}^{3}$ & 1.799 & 3.000 & 13.000 & 5.000 & 6.000 & 7.000 \\
\hline BODIND & 5.382 & 5.000 & 4.000 & 1.716 & 2.000 & 12.000 & 4.000 & 5.000 & 6.000 \\
\hline CEOINTERLOCK & 0.327 & 0 & 0 & 0.470 & 0 & 1.000 & 0 & 0 & 1.000 \\
\hline TOP20_SHR & 0.807 & 0.668 & 0.380 & 2.513 & 0.164 & 42.200 & 0.477 & 0.668 & 0.839 \\
\hline LOGSALES & 5.194 & 5.279 & 0.000 & 0.971 & 0.000 & 7.442 & 4.669 & 5.279 & 5.780 \\
\hline$R O A$ & -0.045 & 0.069 & -30.880 & 1.874 & -30.879 & 0.486 & 0.024 & 0.069 & 0.132 \\
\hline ROS & -0.211 & 0.102 & -73.380 & 4.600 & -73.375 & 3.300 & 0.041 & 0.102 & 0.244 \\
\hline LOSS_DUMMY & 0.142 & 0 & 0 & 0.350 & 0 & 1.000 & 0 & 0 & 0 \\
\hline Profit before Tax & 81239.720 & 17903.000 & -1000.000 & 733474.500 & -7199000.000 & 6297000.000 & 3260.000 & 17903.000 & 54985.000 \\
\hline
\end{tabular}

Panel B: Correlation Analysis

\begin{tabular}{|c|c|c|c|c|c|c|c|c|c|c|c|c|}
\hline Variables & 1 & 2 & 3 & 4 & 5 & 6 & 7 & 8 & 9 & 10 & 11 & 12 \\
\hline $\begin{array}{l}\text { Percentage of_BOD_INTLOCK } \\
\text { (1) }\end{array}$ & 1 & & & & & & & & & & & \\
\hline Log_COMP_INTLOCK (2) & $.637^{* *}$ & 1 & & & & & & & & & & \\
\hline BODSIZE (3) & 0.049 & $.411^{* *}$ & 1 & & & & & & & & & \\
\hline BODIND (4) & $.317^{* *}$ & 0.107 & $-.243 * *$ & 1 & & & & & & & & \\
\hline CEOINTERLOCK (5) & $.247^{* *}$ & $.303^{* *}$ & $.185^{* *}$ & $-.272 * *$ & 1 & & & & & & & \\
\hline TOP20_SHR (6) & -0.073 & 0.055 & -0.015 & -0.049 & -0.053 & 1 & & & & & & \\
\hline CODE (7) & $-.121^{*}$ & -0.105 & 0.091 & -0.115 & 0.048 & 0.062 & 1 & & & & & \\
\hline LOGSALES (8) & $.224^{* *}$ & $.392^{* *}$ & $.564^{* *}$ & -0.063 & $.188^{* *}$ & -0.063 & -0.05 & 1 & & & & \\
\hline$R O A(9)$ & -0.063 & 0.044 & $.178^{* *}$ & 0.05 & 0.043 & -0.004 & 0.05 & $.148^{*}$ & 1 & & & \\
\hline ROS (10) & -0.057 & 0.052 & $.189 * *$ & -0.052 & 0.042 & 0 & 0.037 & $.339 * *$ & $.202 * *$ & 1 & & \\
\hline LOG_TA (11) & $.262^{* *}$ & $.347 * *$ & $.521 * *$ & $.124 *$ & $.140 *$ & -0.095 & -0.098 & $.751^{* *}$ & $.190 * *$ & $.248 * *$ & 1 & \\
\hline LOSS (12) & -0.021 & $-.128^{*}$ & $-.213 * *$ & 0.025 & 0.072 & -0.028 & 0.024 & $-.211 * *$ & $-.200 * *$ & $-.254 * *$ & $-.153^{*}$ & 1 \\
\hline
\end{tabular}

${ }^{* * *}$ Significance at $1 \%$ level; ${ }^{* *}$ significance at $5 \%$ level; ${ }^{*}$ significance at $10 \%$ level.

\footnotetext{
${ }^{3}$ Multiple modes exist. The smallest value is shown
} 
Panel B of Table 2 reports the correlation analysis. Board interlocking directorship is positively correlated with independence of board and CEO interlocking (correlation coefficients are significant at better than 10 percent level, two tail tests), implying that interlocking firms have more independent directors and CEO while heavily involved in other boards. Considering shareholding by the top twenty shareholders (Top20SHR) factor results indicate a negatively correlation with the board interlocking, implying concentrated ownership firms have less independent directors and also less interlocking during the observation period. Firms have less interlocking during the pre-code tenure. It seems that corporate governance codes have positively impacted development of interlocking among New Zealand listed companies. Following univariate analysis will provide more evidence for such relationship. Consistent with expectation, all the variables are significantly correlated with board interlocking.

Table 3 presents a univariate test of difference in mean value for selected variables. During the pre-code period, board interlocking, company interlocking, percent of BOD independence are significantly different than post code period of Interlocking firms. Board interlocking, company interlocking, percent of board independence are significantly different for negative profit firms in compare with loss firm during the observation period. Finally, for firms with CEO interlock and non-CEO interlock firms, board interlock, company interlock, board size and percent of independent directorship are significantly different.

Table 3

Univariate Analysis

\begin{tabular}{|l|c|c|c|c|c|c|c|c|c|}
\hline & \multicolumn{3}{|c|}{ Code } & \multicolumn{3}{c|}{ Loss Dummy } & \multicolumn{3}{c|}{ CEO Interlock } \\
\cline { 2 - 11 } \multicolumn{1}{|c|}{ Variables } & $\begin{array}{c}\text { Pre- } \\
\text { code }(a)\end{array}$ & $\begin{array}{c}\text { Post- } \\
\text { code(b) }\end{array}$ & $\begin{array}{c}\text { mean } \\
\text { difference }\end{array}$ & $\begin{array}{c}\text { +'ve } \\
\text { profit }\end{array}$ & $\begin{array}{c}\text {-'ve } \\
\text { profit }\end{array}$ & $\begin{array}{l}\text { mean } \\
\text { difference }\end{array}$ & $\begin{array}{c}\text { CEO } \\
\text { interlock }\end{array}$ & $\begin{array}{c}\text { CEO not } \\
\text { interlocked }\end{array}$ & $\begin{array}{c}\text { mean } \\
\text { difference }\end{array}$ \\
\hline BOD interlock & 0.831 & 0.777 & $2.01^{* *}$ & 0.80 & 0.72 & $0.345^{*}$ & 0.886 & 0.769 & $-4.22^{* * *}$ \\
\hline $\begin{array}{l}\text { Company } \\
\text { interlock }\end{array}$ & 1.356 & 1.274 & $1.74^{*}$ & 1.34 & 1.19 & $2.216^{* * *}$ & 1.488 & 1.238 & $-5.23^{* * *}$ \\
\hline BODSIZE & 0.785 & 0.808 & -1.51 & 0.81 & 0.72 & $3.605^{* * *}$ & 0.827 & 0.779 & $-3.12^{* * *}$ \\
\hline BODIND & 0.853 & 0.819 & $1.91^{* *}$ & 0.83 & 0.85 & $-0.420^{*}$ & 0.780 & 0.867 & $4.67^{* * *}$ \\
\hline $\begin{array}{l}\text { CEOINTERL } \\
\text { OCK }\end{array}$ & 0.31 & 0.35 & -0.79 & 0.31 & 0.41 & -1.191 & & & \\
\hline TOP20SHR & 0.672 & 0.985 & -1.03 & 0.83 & 0.64 & 0.465 & 0.617 & 0.910 & 0.88 \\
\hline LOGSALES & 5.23 & 5.13 & 0.81 & 5.27 & 6.25 & $3.51^{* * *}$ & 5.465 & 5.072 & $-3.11^{* * *}$ \\
\hline ROA & -0.127 & 0.623 & -0.83 & 0.112 & -0.965 & $3.37 * * *$ & 0.071 & -1.021 & -0.71 \\
\hline ROS & -0.361 & -0.017 & -0.61 & 0.22 & -3.35 & $4.25^{* * *}$ & 0.771 & -0.341 & -0.68 \\
\hline LOG_TA & 5.54 & 5.36 & $1.64 *$ & 5.51 & 5.12 & $2.56^{* *}$ & 5.631 & 5.372 & $-2.33^{*}$ \\
\hline LOSS & 0.13 & 0.15 & -0.39 & & & & 0.18 & 0.12 & $-1.91^{*}$ \\
\hline CODE & & & & 0.43 & 0.46 & -0.391 & 0.47 & 0.42 & -0.79 \\
\hline
\end{tabular}

$* * *$ Significance at $1 \%$ level; ${ }^{* *}$ significance at $5 \%$ level; * significance at $10 \%$ level. 
4.1 What determines board interlocking in New Zealand?

Analysis of the multivariate results implies the following: although univariate analysis reveals some interesting insights, the results do not control for other known determinants of board interlocking choice. Table 4 examines the determinants of board interlocking and company-tocompany interlocking in New Zealand. Both the distress coefficients are positive and statistically significant at better than 1\% level. Board size and percent of independent directors are positive and statistically significant which indicates that firms with large board size and more independent board have more interlocking directors. Alternatively, CODE (corporate governance code) is negative and statistically significant at 1\% level. This result indicates that after 2003 (post code period) directors are experiencing less interlocking in New Zealand. CEO interlock is positive and statistically significant with board and company-to-company interlocking, implying that firms have more interlocking directors and more company interlock when the CEO is also interlocked. However, the results of TOP20SHR are mixed. The positive coefficient with Log of Sales indicates that firms with more operating complexity have more interlocked directors. However, firm size proxy as Log of Total Assets shows mixed results with the board and company-to-company interlocking.

\section{Table 4}

\section{Regression analysis: Interlocking equation}

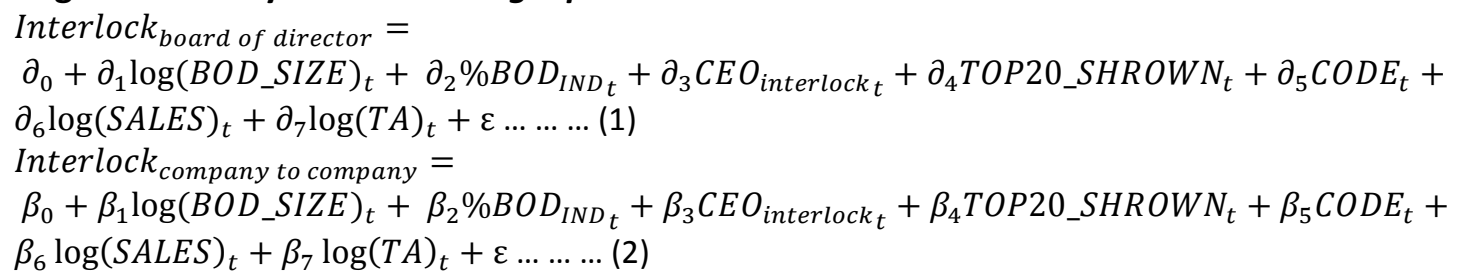

\begin{tabular}{|l|c|c|c|}
\hline Variables & Predicated Signs & Board Interlock (Coefficient) & Company to Company interlock (Coefficient) \\
\hline Constant & & 0.26 & $-0.471^{* * *}$ \\
\hline BODSIZE & + & $0.48^{* * *}$ & $1.08^{* * *}$ \\
\hline INDDIR & + & $0.59^{* * *}$ & $0.751^{* * *}$ \\
\hline CODE & $?$ & $-0.30^{* * *}$ & $-0.096^{* *}$ \\
\hline CEOINTERLOCK & + & $0.146^{* *}$ & $0.268^{* * *}$ \\
\hline TOP20SHR & $-/+$ & -0.01 & $0.016^{* *}$ \\
\hline LOGSALES & $+/-$ & 0.03 & $0.097^{* *}$ \\
\hline LOG_TA & $+/-$ & 0.025 & -0.047 \\
\hline & & & $1.48^{* * *}$ \\
\hline F-value & & $13.67^{* * *}$ & 0.329 \\
\hline Adjusted R-Square & & 0.251 & \\
\hline
\end{tabular}

*** Significance at $1 \%$ level; ${ }^{* *}$ significance at $5 \%$ level; ${ }^{*}$ significance at $10 \%$ level. 
Where; Interlock board of director $=$ total number of interlocking in the board with other firms board (board interlocking); Interlock company to company = total number of interlocking in the board with other firms (company to company interlocking); $R O A=$ a proxy of firm performance, ratio of net income and total assets; ROS= a proxy of firm performance, ratio of total sales and total assets; LOSS_DUMMY= a proxy of firm performance, value of 1 if negative profit during the financial year, otherwise $0 . \log \left(B O D_{\text {SIZE }}\right)=$ natural log of total number of directors in the board; \%BOD IND = percentage of total number of independent board members; $C E O$ interlock $=a$ dichotomous variable of CEO interlock measure. A value of ' 1 ' is assigned if CEO is an interlocking member and ' $O$ ' otherwise; CODE= $a$ dichotomous variable of 1 if observation is pre-corporate governance code, 0 otherwise; TOP2O_SHROWN = total percentage of share hold by the top twenty shareholder; LOg (SALES) = log value of sales, a proxy of firm operating complexity; $\log (T A)=$ natural log of total assets as a proxy of firm size.

Taken together with both the regression results, (1) \& (2) provide evidence that boards are more interlocked when the board size is larger and with more independent directors. CEO interlocks also influence the interlocking directorship for firms in New Zealand. This result is consistent with Devos, Prevost and Puthenpurackal (2009) with the finding that shareholders react negatively to the formation of director interlocks and reduced sensitivity of CEO turnover to firm performance.

\subsection{Effects of interlocking in New Zealand firms}

Table 5 examines the firm performance when interlocking exists. All the three performance (ROA, ROS, LOSS Dummy) coefficients are negative with board interlocking and company-tocompany interlocking. Board interlocking is negative and statistically (at 1 to 10\% level) significant for ROA, ROS and Loss Dummy. Company-to-company is negative and statistically significant (at 1 to 10\% level except LOSS DUMMY) with ROA and ROS.

Board size coefficient is positive and statistically significant (at 1 to $10 \%$ level) with ROA but negative significance with ROS and LOSSDUMY. Percent of independent director has positive coefficient with board interlocking and company-to-company interlocking for all the performance measure ROA, ROS and LOSS DUMMY. CEO interlock has negative coefficient with ROS for both interlocking measure with no significance but positive coefficient with ROA and LOSS dummy having no significance. Corporate governance code has positive coefficient with board and company-to-company interlocking for all three measures but mixed coefficient for TOP20SHR. 
Table 5

Regression Analysis: Interlocking performance regression

$R O A_{t}=\partial_{0}+\partial_{1} \log \left(B O D_{-} S I Z E\right)_{t}+\partial_{2} \%$ BOD $_{\text {IND }}+\partial_{3}$ CEO $_{\text {interlock }_{t}}+\partial_{4}$ TOP $20 \_S H R O W N_{t}+\partial_{5}$ CODE $E_{t}+$ $\partial_{6} \log (S A L E S)_{t}+\partial_{7} \log (T A)_{t}+\partial_{8}$ Interlock $_{\text {board of director }}+\varepsilon \ldots \ldots \ldots$ (3)

$R_{O} O S_{t}=\partial_{0}+\partial_{1} \log \left(B O D_{-} S I Z E\right)_{t}+\partial_{2} \% B O D_{I N D_{t}}+\partial_{3} C E O_{\text {interlock }_{t}}+\partial_{4}$ TOP20_SHROWN $N_{t}+\partial_{5}$ CODE $_{t}+$ $\partial_{6} \log (S A L E S)_{t}+\partial_{7} \log (T A)_{t}+\partial_{8}$ Interlock $_{\text {board of director }}+\varepsilon \ldots \ldots \ldots$ (4)

LOSS_DUMMY $_{t}=\partial_{0}+\partial_{1} \log \left(B O D_{-} S I Z E\right)_{t}+\partial_{2} \% B O D_{\text {IND }}+\partial_{3} C E O_{\text {interlock }_{t}}+\partial_{4}$ TOP20_SHROWN $N_{t}+$ $\partial_{5} C_{O D E}+\partial_{6} \log (S A L E S)_{t}+\partial_{7} \log (T A)_{t}+\partial_{8}$ Interlock $_{\text {board of director }}+\varepsilon \ldots \ldots \ldots$ (5)

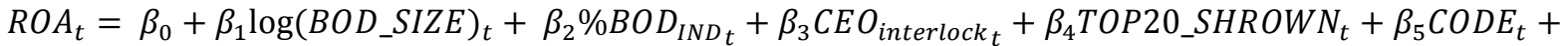
$\beta_{6} \log (\text { SALES })_{t}+\beta_{7} \log (T A)_{t}+\beta_{8}$ Interlock ${ }_{\text {company to company }}+\varepsilon \ldots \ldots \ldots$ (6)

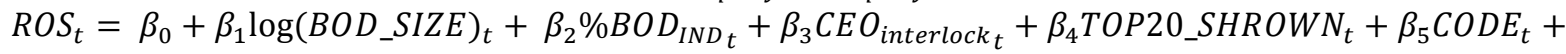
$\beta_{6} \log (\text { SALES })_{t}+\beta_{7} \log (T A)_{t}+\beta_{8}$ Interlock company to company $+\varepsilon \ldots \ldots \ldots$ (7)

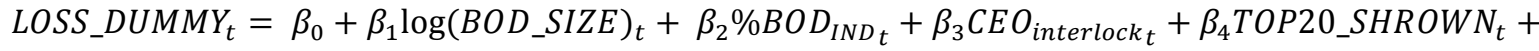
$\beta_{5} C_{C O D E_{t}}+\beta_{6} \log (S A L E S)_{t}+\beta_{7} \log (T A)_{t}+\beta_{8}$ Interlock $_{\text {company to company }}+\varepsilon$.

\begin{tabular}{|l|c|c|c|c|c|c|c|}
\hline \multirow{2}{*}{ Variables } & \multirow{2}{*}{ Predicted sign } & \multicolumn{3}{c|}{ Board interlocking } & \multicolumn{3}{c|}{$\begin{array}{c}\text { Company to company } \\
\text { interlock }\end{array}$} \\
\cline { 3 - 8 } & & ROA & ROS & $\begin{array}{c}\text { LOSS } \\
\text { Dummy }\end{array}$ & ROA & ROS & $\begin{array}{c}\text { LOSS } \\
\text { Dummy }\end{array}$ \\
\hline Constant & & $-4.09^{* * *}$ & $-8.85^{* * *}$ & $0.46^{* *}$ & -4.40 & -9.34 & $0.472^{* *}$ \\
\hline $\begin{array}{l}\text { Percentage of } \\
\text { board interlocking }\end{array}$ & $?$ & $-1.49^{* * *}$ & $-2.27^{* * *}$ & $-0.67^{*}$ & & & \\
\hline $\begin{array}{l}\text { Company to } \\
\text { company } \\
\text { interlocking }\end{array}$ & & & & & & \\
\hline BODSIZE & $?$ & & & & $-0.416^{*}$ & $-0.41^{*}$ & -0.21 \\
\hline INDDIR & & & & & & & \\
\hline CEOINTERLOCK & + & $1.98^{*}$ & $-1.80^{*}$ & $-0.413^{* *}$ & $2.57^{* *}$ & $-1.20^{*}$ & $-0.41^{* *}$ \\
\hline TOP20SHR & + & $1.87^{* *}$ & $1.04^{*}$ & 0.49 & $1.31^{*}$ & 0.06 & 0.26 \\
\hline CODE & + & 0.24 & -0.38 & 0.03 & 0.14 & -0.265 & 0.25 \\
\hline LOGSALES & $-/+$ & 0.08 & 0.31 & -0.03 & 0.02 & 0.04 & -0.03 \\
\hline LOG_TA & $+/-$ & -0.03 & $2.44^{* * *}$ & $-0.10^{* * *}$ & -0.36 & $2.48^{* *}$ & $-0.10^{* *}$ \\
\hline & $+/-$ & $0.38^{* * *}$ & -0.37 & $0.92^{* *}$ & $0.327^{*}$ & -0.48 & $0.09^{* *}$ \\
\hline F-value & & & & & & & \\
\hline Adjusted R-Square & & $2.769^{* * *}$ & $5.016^{* * *}$ & $2.90^{* * *}$ & $2.13^{* *}$ & $4.69^{* * *}$ & 2.95 \\
\hline
\end{tabular}

*** Significance at $1 \%$ level; ${ }^{* *}$ significance at $5 \%$ level; * significance at $10 \%$ level.

Where; Interlock board of director = total number of interlocking in the board with other firms board (board interlocking); Interlock companytocompany = total number of interlocking in the board with other firms (company to company interlocking); $R O A=$ a proxy of firm performance, ratio of net income and total assets; ROS=a proxy of firm performance, ratio of total sales and total assets; LOSS_DUMMY= a proxy of firm performance, value of 1 if negative profit during the financial year, otherwise $0 . \log \left(B O D_{\text {SIZE }}\right)=$ natural log of total number of directors in the board; $\% B O D_{I N D}=$ percentage of total number of independent board members; $C E O$ interlock $=$ a dichotomous variable of CEO interlock measure. A value of ' 1 ' is assigned if CEO is an interlocking member and ' $O$ ' otherwise; CODE= $a$ dichotomous variable of 1 if observation is pre-corporate governance code, 0 otherwise; TOP2O_SHROWN = total percentage of share hold by the top twenty shareholder; $\log (S A L E S)=\log$ value of sales, a proxy of firm operating complexity; $\log (T A)=$ natural log of total assets as a proxy of firm size. 


\section{Conclusion and future research}

This study empirically identified and examined the determinant and consequences of board and company to company interlocking in the New Zealand business context. The study used both board and director levels of connectedness to measure the interlocking. As the managerial labour market has a shortage of independent and qualified directors in New Zealand, the effectiveness of corporate governance is questionable and suggests further investigation is warranted.

Using a two-fold approach of firm interlocking such as board interlocking and companyto-company interlocking, this research found evidence that New Zealand firms are significantly interlocked in both situations which causes negative performance of these firms as an immediate consequence. The interlock exhibited no effect on corporate governance best practice codes while a negative reaction was found for ownership concentrated firms. The study also flagged that interlocking behaviour affected by the CEO interlocking in New Zealand. However, this research will hopefully lead to further research on managerial discretion on earnings management. Due to the relaxed regulatory environment, interlocked director(s) could be members of audit committees that may lead to conflicts of interest; this is a unique situation that should receive future research. Monitoring effectiveness could be another avenue of research for the interlocking firms in New Zealand.

This research has potential applicability to New Zealand regulatory agencies such as the Financial Market Authority (FMA) to evidence the close ties of top management to other firms. The New Zealand Institute of Directors could be another potential regulator who might benefit from the findings of this study to discourage CEO interlocking in New Zealand.

\section{References}

Ahn, S., Jiraporn, P., \& Kim, Y. (2010), Multiple Directorship and Acquirer Returns. Journal of Banking \& Finance, Vol. $34, \quad$ pp. 20112026. http://dx.doi.org/10.1016/j.jbankfin.2010.01.009

Beasley, M. S. (1996), An Empirical Analysis of the Relation between the Board of Director Composition and Financial Statement Fraud. The Accounting Review, Vol. 71 No. 4. pp. 443-465.

Bhuiyan, Md., \& Habib, A. (2011), Determinants of Nomination Committee: New Zealand Evidence. Corporate Board: Role, Duties \& Composition, Vol. 7 No. 2. pp. 54-64.

Bowen, R. M., Rajgopal, S., \& Venkatachalam, M. (2008), Accounting Discretion, Corporate Governance, and Firm Performance, Contemporary Accounting Research, Vol. 25 No. 2, pp. 351-405. http://dx.doi.org/10.1506/car.25.2.3

Biggins, J. V. (1999), Making Board Diversity Work, Corporate Board, Vol. 20 No. 117, pp. 11-17.

Core, J. Robert H. and Larcker, D. (1999), Corporate governance, chief executive officer compensation, and firm performance, Journal of Financial Economics 51, 371406. http://dx.doi.org/10.1016/S0304-405X(98)00058-0

Devos, E., A. Prevost, and J. Puthenpurackal. (2009), Are Interlocked Directors Effective Monitors? Financial Management, Winter, pp. 861-887. http://dx.doi.org/10.1111/j.1755-053X.2009.01059.x 
Fama, E. and Jensen, M. (1983), The separation of ownership and control. Journal of Law and Economics Vol. 26. pp. 301-325. http://dx.doi.org/10.1086/467037

Farrar, J. (2005), Corporate Governance: Toothless Tiger - All roar and no bite. New Zealand Management, August, Vol. 72. pp. 72.

Ferris, M, and Pritchard, A. (2003), Too busy to mind the business? Monitoring by directors with multiple board appointments, Journal of Finance, Vol. 58, pp. 1087-1111. http://dx.doi.org/10.1111/1540-6261.00559

Financial Market Authority. (2013). New directors' guide aimed at sharpening up corporate governance (16 April ed). Retrieved 29 January 2014, from http://www.fma.govt.nz/helpme-invest/getting-the-right-information/brochures

Finch, E., and Shivdasani, A. (2006), Are Busy Boards Effective Monitors? The Journal of Finance, Vol. No. LXI (2). pp. 689-724.

Goldfinch, M. (2004). Do the NZSE listing rules destroy value? University of Auckland Business Review, Vol. 6. No. 1, pp. 1-10.

Hossain, M. Prevost, A. and Rao, P. (2001), Corporate Governance in New Zealand: The effect of the 1993 Companies Act on the relation between board composition and firm performance. Pacific Basin Finance Journal, Vol. 9 No. 2. pp. 119-145. http://dx.doi.org/10.1016/S0927-538X(01)00003-8

Hunton, J. and Rose, J. (2008). Can directors' self-interests influence accounting choices? Accounting, Organizations and Society, Vol. 33, pp. $783-800$ http://dx.doi.org/10.1016/j.aos.2007.10.001

Keys, P., \& Li, J. (2005). Evidence on the market for professional directors. The Journal of Financial Research, Vol. 28, pp. 575 - 589 http://dx.doi.org/10.1111/j.14756803.2005.00140.x

Mace, M. (1986). Directors: Myth and Reality. Boston, MA: Harvard University Press.

Mizruchi M. (1996), What do interlocks do? An analysis, critique, and assessment of research on interlocking directorates. Annual Review of Sociology, Vol. 22. pp. 271- 98. http://dx.doi.org/10.1146/annurev.soc.22.1.271

Murray, G. (2006). Capitalist Networks and Social Power in Australia and New Zealand. London: Ashgate Publishing Limited

Parker, T. (2012). Faces at top of the chain, The New Zealand Herald. Retrieved from http://www.nzherald.co.nz/business/news/article.cfm?c_id=3\&objectid=10834460

Singh, V., Vinnicombe, S. and Johnson, P. (2000), Women Directors on Top UK Boards. Paper resented at 3rd International Conference on Corporate Governance and Direction, Henley, UK, 16-18 October, pp. 28

Silva, F., Nicolas, M. and Paredes, R. (2006). Family ties, interlocking directors and performance of business groups in emerging countries: The case of Chile, Journal of Business Research, Vol. 59, pp. 315 - 321. http://dx.doi.org/10.1016/j.jbusres.2005.09.004 